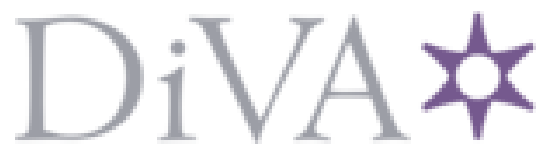

http://www.diva-portal.org

This is the published version of a chapter published in Life Histories of Etnos Theory in Russia and Beyond.

Citation for the original published chapter:

Arzyutov, D. (2019)

Order Out of Chaos: Anthropology and Politics of Sergei M. Shirokogoroff

In: Anderson, David; Arzyutov, Dmitry; Alymov, Sergei (ed.), Life Histories of Etnos

Theory in Russia and Beyond Cambridge: Open Book Publishers

https://doi.org/10.11647/OBP.0150.06

N.B. When citing this work, cite the original published chapter.

Permanent link to this version:

http://urn.kb.se/resolve?urn=urn:nbn:se:kth:diva-259922 


\title{
6. Order out of Chaos: Anthropology and Politics of Sergei M. Shirokogoroff
}

\author{
Dmitry V.Arzyutov
}

Vaniushin fell out of [Merkulov's] car [...]: in the past two days he had been drinking hard in the company of a new member of the government - Serge Shirokogoroff. An ethnographer and biologist, Shirokogoroff had his own vision of the ends and beginnings of human evolution and had the gift of telling his stories in such a way that one couldn't refrain from drinking. According to his logic, no matter what one did there was no way to avoid the onset of the beastliness in the world (Semënov 1994 [1966]: 316-17).

Through this unexpected passage from the popular Soviet-era spy thriller series featuring Max Otto von Stierlitz, one of the central authors of Russian etnos theory entered Soviet popular culture. The patriotic and duplicitous theme of these novels, which featured a Soviet agent embedded in the heart of the Nazi war machine, in a sense parallels the intellectual career of Sergei M. Shirokogoroff. While known in Europe and North America primarily as a scholarly student of shamanism, Shirokogoroff also lived a second life: he was a political actor, as well as a pamphleteer, both collaborating with and protesting against the Merkulov brothers' short-lived breakaway administration within the provisional government of Priamur'e (1921-1922), and before that, one of several anti-Bolshevik governments in the Russian Far East 
(1918-1920) (Lîakhov 2013; Stephan 1978). Later in his career, living in Japanese-occupied Manchukuo, he collaborated with scholars working under the Japanese imperial regime and took a one-year sabbatical to work with ethnographers working within Nazi Germany.

In this chapter, I draw a panoramic picture that connects Shirokogoroff's dissenting political work to his theoretical work on etnos. I will show how, throughout his intellectual life and especially during the political chaos engendered by the collapse of the Russian Empire, Shirokogoroff developed his theory in the context of public debates with the Bolshevik and socialist movements in the Russian Far East, and later deployed it as a political tool aimed against Soviet power when he lived in China. His political publications are a lens though which we can understand the history of etnos theory as one reflecting the political chaos in Russia and Eurasia at the start of the twentieth century.

\section{Ethnographer, Politician, Shaman}

Shirokogoroff's cameo role in IUlian Semënov's 1966 novel No Password Required placed him close to the heart of the Merkulov administration and identified him as a person intimately connected to the political landscape of the Russian Far East (Fig. 6.1). Semënov used his artistic license to dramatize our hero and in places muddied the facts. It is true that for a short time in 1921 and 1922, Shirokogoroff served as a secretary to the local Parliamentary Assembly (Narodnoe Sobranie) following the coup launched by the Merkulov brothers (SPF ARAN 1421(1924)-4: 11). Earlier, in 1918, Shirokogoroff's political life also put him in the company of a different short-lived anti-Bolshevik administration as the head of the Diplomatic Chancellery of the Provisional Priamur'e Government in Vladivostok (MRC SF 45-3-9; 45-4-1).

The depth of Shirokogoroff's engagement with these two antiSoviet administrations, and his interest in regional politics is generally not well known, and is not discussed or even mentioned in any of his existing published biographies. According to his own account, these positions provided him a good opportunity to "observe the mechanisms of the [political process] while at the same time reading lectures on ethnography" (BN PAU i PAN 4600-6: 5). In another report, he states that he served the Merkulov parliament only until 


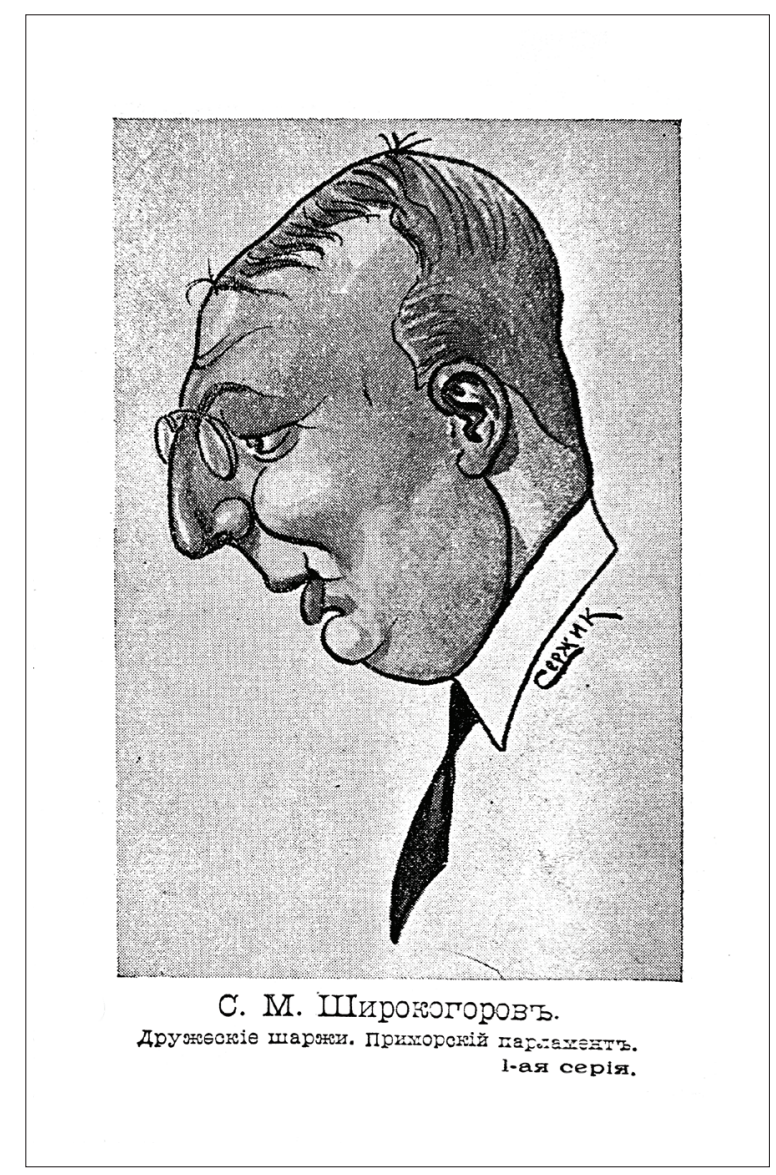

Fig. 6.1 Sergei Shirokogoroff ("Serzhik") as a member of the Primorskiŭ parliament (MRC: unnumbered). (C) Museum of Russian Culture, San Francisco, California

such time as "it was disbanded by still another government in a series of administrations" (SPF ARAN 142-1(1924)-4: 12v). Shirokogoroff's dispassionate evaluation of the galloping change around him captures the flavour of the period that Jonathan Smele describes as "the compound compendium of overlapping wars and conflicts in a disintegrating imperium" which he christens, in the plural, as the Russian Civil Wars (Smele 2015b: 7). Shirokogoroff himself hinted at the importance of this period of his life to his ethnographic work and offered a no less colourful portrait of himself in one of his last letters to Lev Shternberg, written in 22 December 1922. This passage connects 
rather well to the theme of subterfuge and intrigue that the novelist Semënov highlighted:

I was able to use only a small part of my observations and conclusions for my Étnos [1923]. When I was forced to leave the Tunguses and the Manchus to one side, as well as the other nice peoples, and found myself in the company of all kinds of Europeans, including some Russians, I involuntarily developed a habit of studying them as an "ethnographer". This created a psychologically very curious situation - a feeling of complete isolation from all and sundry, and a monstrous, never until then experienced, desire to "observe". I've always felt and still feel an observer in public and could only be myself sitting behind my desk. It was roughly the same feeling as the one I had in the capacity of a shaman's assistant, or a Manchu jury member whose business was to elect a new shaman.

Particularly often this quid pro quo happened when I served as the People's Assembly secretary in Vladivostok. Because no one apart from [my wife,] Eliz[aveta] Nik[olaevna,] could know of my interest in these observations, I had to be a true shaman, find the right approaches, etc. (SPF ARAN 282-2-319: 26-26v).

This extract offers at least one clue to the origin of Shirokogoroff's version of etnos theory. It suggests that the theory owes its conception to both the political instability in Vladivostok and Shirokogoroff's own conservative and (sometimes) vehemently anti-Bolshevik political beliefs. This passage allows us to expand our view of his "field" to include not only his pioneering fieldwork in Zabaĭkal'e (see chapter 5), but also to include the way that he honed his observational skills in the seething political environment in eastern Eurasia.

A key notion in both contexts is his concept of an "equilibrium" (ravnovesie), which he sought to apply to Tungus ethnography within the context of the deep political crisis in his own country. Much later, first when he was living in the capital of nationalist China in Canton [Guăngzhōu] and then in Beiping [Běijing] during the Japanese occupation, he would attempt to apply his theories of "ethnical equilibriums" to the major political movements unsettling Europe at the dawn of World War II. His extensive correspondence with ethnographers within Nazi Germany and with Nazi-sympathizers within England, is also not well known. In this correspondence, etnos theory emerges as an imaginary sociological and anthropological ideal 
where order exists through the overlapping of an ideal past and an ideal future, eclipsing the present, which is dismissed as chaos. In order to trace the theme of "order through chaos" I propose to review Shirokogoroff's personal and ethnographic biography with an eye to the political movements he allied himself with in his youth and at the height of his career.

\section{Vol'sk and IUr'ev: Political Life in the Provinces}

Sergei Mikhailovich Shirokogoroff was born in Suzdal' to the family of the pharmacist Mikhail Ivanovich (1862/63-?) and Aleksandra IUl'evna Shirokogorov in 1887. At some point, the family moved to Vol'sk, where Sergei's father served as a member of the Vol'sk town council from 1907 to 1916. This provincial Russian town played an important role in Russian revolutionary politics in the days preceding the first Russian revolution. Aleksandr Fedorovich Kerenskiü, whose business as a lawyer often brought him to Vol'sk, was elected to the State Duma from a constituency in Vol'sk. In the Duma, he led the Trudoviki faction of the Socialist Revolutionary Party and was a prominent official in a number of posts in the provisional government (Kerensky 1965). This moderate socialist party was later overthrown by the Bolshevik faction during the second Russian revolution.

According to contemporary descendants of the Shirokogorov family, Natal'ía and Vladimir Shirokogorov, Kerenskiĭ was a frequent guest in the Shirokogorov's home (pers. comm., 25 Jan. 2017), perhaps indicating that Sergei's family was involved in the political life of a provincial town and to some extent sympathetic to socialist ideals. It was said that Kerenskiǔ was also courting Sergei's cousin, Evgeniía. In addition, it is also known that Sergei's father was at the centre of events during the 1905 revolution. Natal'ia Shirokogorova noted that the Shirokogoroff pharmacy was used as a safe house by the revolutionaries. She further noted that, during a demonstration on 20 October 1905, Mikhail Ivanovich was heavily beaten by the members of the monarchist and nationalist movement known as "The Black Hundreds" (Chernosotenfsy), after which he had to spend over a month in hospital (pers. comm.). 


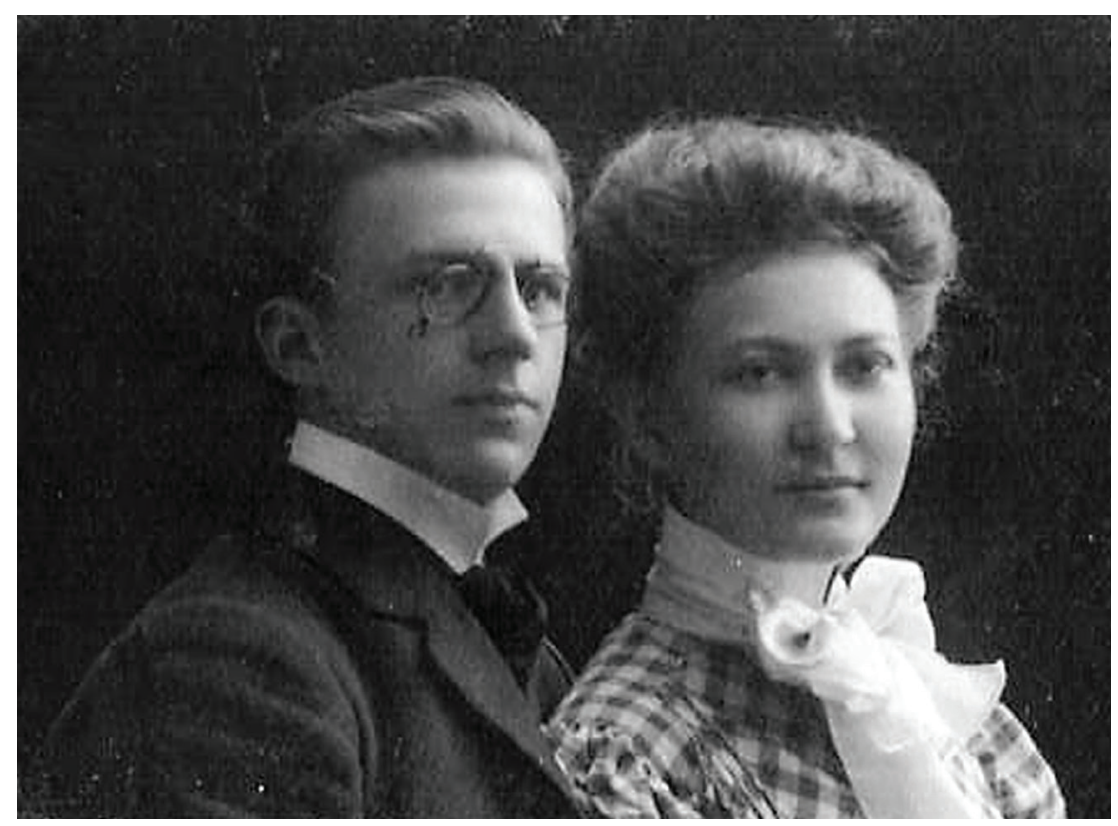

Fig. 6.2 Sergei Shirokogoroff and Elizaveta Robinson, 1906 (EVR)

The Shirokogoroff family also maintained close ties with the city of IUUr'ev (now known as Tartu, Estonia). This was the home of Sergei's uncle, Ivan Ivanovich Shirokogorov (1869-1946), who was an outstanding and internationally renowned anatomist and pathologist and University Professor of Anatomical Pathology (EAA 384.1.3443; EAA 402.1.29600; EAA 402.3.1864). Ivan's brothers Vladimir (1885-?) and Mikhaill (1892?) also studied law and history at IUr'ev University (EAA 402.1.29599; EAA 402.1.29601; EAA 402.1.29602). Sergei visited the city, and later moved there in 1903 to complete his primary education at the Hugo Treffner Gymnasium (TsGIA SPb 14-3-59098: 3-3v). In IUr'ev, he met the woman who would become his wife: Elizaveta [Elizabeth] Robinson (1884-1943) (Fig. 6.2). According to Elena V. Robinson, both Sergei and Elizaveta travelled to Paris to continue their studies in 1906 or 1907 (pers. comm., May-June 2016). It is likely that their study placement at the Sorbonne was organized through Ivan Shirokogorov's international connections, as he himself would be seconded to the Pasteur Institute in 1908 (Chirokogorov 1909).

While Sergei and Elizaveta were pursuing their studies in Paris, Sergei's brother Vladimir, then an undergraduate student at IUr'ev 
University, became embroiled in student protest movements, which caused a lot of embarrassment to his uncle Ivan. Ivan Shirokogorov was forced to write numerous letters of support and explanation to the university leadership in a vain attempt to save his nephew's career. In the end, Vladimir was not allowed to finish his university education (EAA 402.1.29599; GARF 102 D-7-207(1910)-2877). While these dramas were unfolding in IUr'ev, Sergei and Elizaveta were developing their own contacts and alliances in Paris, not to mention formalizing their relationship with their marriage in 1908 at the Nevskii cathedral in Paris (TumA 243).

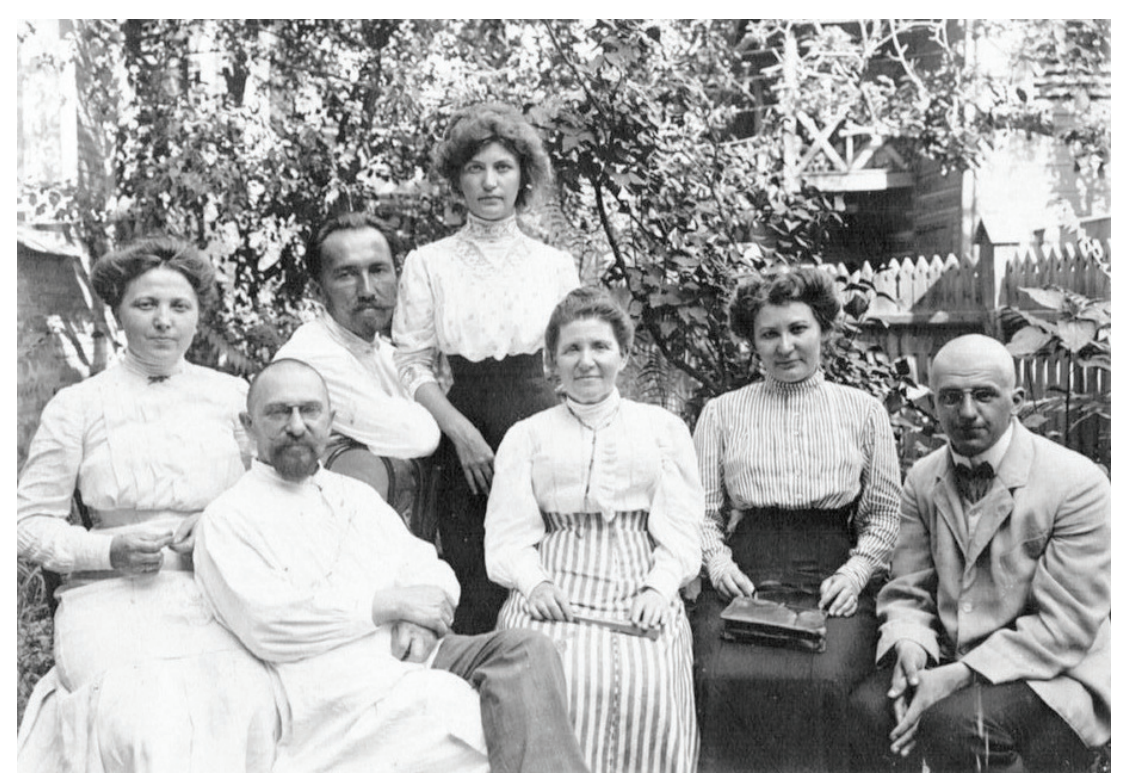

Fig. 6.3 Sergei Shirokogoroff with Elizaveta's family, June 1911 (EVR). First row, right to left: Serger M. Shirokogoroff, Elizaveta (Lilia) Nikolaevna Robinson, Nadezhda Fëdorovna Robinson (Elizaveta's mother), Nikolaĭ Fedorovich Gamburger (Elizaveta's maternal uncle). Second row, left to right: the wife of Nikolaı̆ F. Gamburger, Mikhail Nikolaevich Smirnov (Mariîa N. Robinson's husband), Mariîa (Mura) Nikolaevna Robinson

Sergei's correspondence from this period, intercepted and filed by the Russian secret police, gives us our first clues as to his political identity. 


\section{Paris: on the "Degeneration" of Political Parties}

It is difficult to say what made Sergei and Elizaveta go to Paris (Fig. 6.4). We might assume that their parents wanted to give their children a good education while protecting them from the instability already developing in Russia. It is curious that, despite being free from the political distractions that scuttled his cousin's career, Sergei never completed a university degree. His education was limited to his attendance at the Paris University's Faculté des Lettres from 1907 to 1910, where he audited courses (lecteur des lettres) (TsGIA SPb 14-359098; RGIA DV P-289-2-1573: 27). He also attended some lectures at L'École d'anthropologie de Paris and at L'École pratique des hautes études, likely in an unofficial capacity.

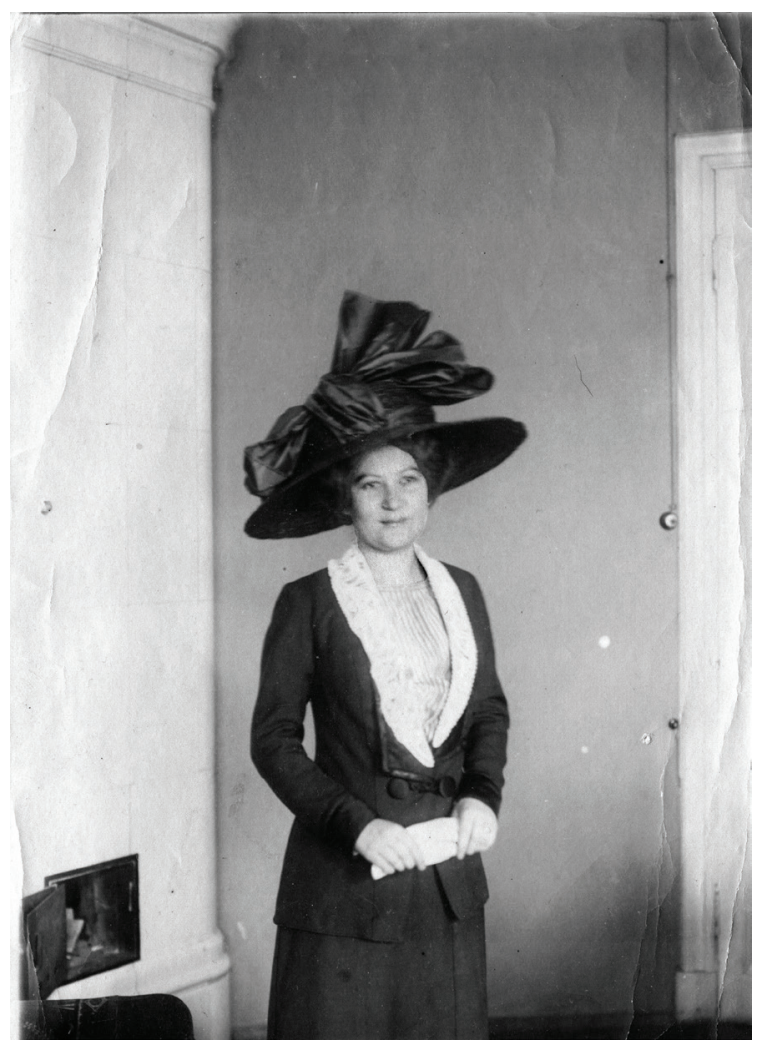

Fig. 6.4 Elizaveta Robinson in Paris (EVR) 
Sergei's polymathic interest in various courses in politics and physical anthropology is probably not that unusual for an era before the professionalization of anthropology. However, it is important to correct the record since some Russian historians credit him with taking a docteur des lettres at the Sorbonne (Reshetov 2001: 8). Later, in Vladivostok and China, Shirokogoroff himself used his French training to provide the justification for his title of professor.

While living in Paris on the Boulevard Saint-Germain, Sergei often and regularly wrote home to Russia. He wrote one letter on 10 January 1910 to Lev (Shlema-Leiba) Efimovich (Khaimovich) Berkovich (1863-1911), his former neighbour in Vol'sk and the former leader of a so-called Marxist group. This letter was intercepted by the secret police on 2 March 1910 and presumably did not reach its addressee, but instead found its way to the Hoover Institution Archives in Stanford:

I live quite far from the Russian colony. Do not go anywhere. However, sometimes I am told curious things. I'll tell you what I know. The process of our [Russian] parties' degeneration is, of course, in full swing. And everyone is degenerating in their own way. This, to my mind, is the most interesting aspect of it all. [...] All their activity in the meanwhile is reduced to desperate squabbles on entirely personal grounds. And if you add to all this the fact that all of them are busy with "settling down", concentrate on their petty businesses, prepare for careers as lawyers, administrators, judiciary and others, policemen, provocateurs, medical doctors, authors, etc. as best they can - no holds barred. This is what degeneration really means. What will be left over? Apparently, the "students" without the "teachers". And we'll start telling the tale from the beginning, only, in all probability, in a different manner. A mood of depression everywhere and there's nothing to help it. Russian history, apparently, went through a certain stage and now neither the "students", nor the "teachers" can quite recover from the experience (HILA 26001/141, emphasis added).

From a historical point of view, this passage reflects a bitter disappointment to political hopes of the Russian society after the upheavals of 1905-1907. This fragment about the degeneration of political parties is, in my opinion, important for the understanding of what Shirokogoroff would write several years later in his self-published political brochures, proclaiming that parties cannot form a foundation of the state or the nation. In his academic or educational texts he preferred to employ the "scientific" term etnos, reserving "nation" and 
"state" solely for his political writing. However, I would argue that the meanings are more or less the same.

In this period Sergei became infatuated with comparative ethnology, which he pursued through intensive reading in the Paris National Library. Some years later he would recollect in a letter to his friend Władysław Kotwicz, a Russian-Polish linguist:

Having arrived in Petersburg with an already significant theoretical knowledge base, I immediately felt the difference in methodology of what could be called "philosophy", and even the research interests and competence. After all, by that time I had already been studying these disciplines for over five years [...] [One] very large and meticulous work I was completing in my first year in Petersburg was on the application of statistical analysis methods to the problems of the forms of social organization and conditions [for the development] of technical culture, as well as the relationship with the primary environment. I worked with almost over two thousand peoples, predominantly from Africa, India, and America, the literature on which was mostly available to me in the National Library in Paris. (I must say that I wasn't much interested in Siberia at the time). I discarded the idea of that type of correlation after I finished that work; however there was a certain positive result: I became familiar with a number of peoples, literature, methodology, and the formulation of problems (BN PAU i PAN 4600-7: 55, 6 Feb. 1933).

His "statistical" interest in comparative examples would find its way into his published works on ethnology, as well as the political brochures that he would publish during his association with the Merkulov administration. Some of his reading notes taken from Paris libraries survive to this day (SPF ARAN 849-5-805). Written primarily in French and Russian, they show a wide reading of works in theoretical ethnology ranging from Marcel Mauss to Edward Tylor (Ibid: 204-05v), as well as curiosity about a variety of cultures, economies and political systems across the globe.

We also may presume that, as a student, Shirokogoroff witnessed some of the discussions taking place in Paris about how to distinguish ethnological research from sociological or (physical) anthropological research. For example, Georges Papillault (1908) - who likely was one of Shirokogoroff's lecturers - published an overview of ethnology's place among all the sciences that looks similar, if not identical, to an overview that Shirokogoroff himself would publish in Vladivostok (Shirokogorov 1922a). Papillault's overview also recommended the use of the term 
"etnos" to denote the study of peoples (peuples) who, irrespective of racial differences, presented themselves as one community (Papillault 1908: 127). Although there is no direct evidence of an intellectual link between Papillault's lecturers in Paris, and Shirokogoroff's career in Petrograd, Vladivostok, and Beiping, it is a remarkable coincidence that the debate over the definition of ethnology as a discipline, and the methods needed to define an etnos, would come to dominate his political and ethnographic writing upon his return to Russia.

\section{Between Petrograd and the Far East}

After his return from Paris, Sergei Shirokogoroff began a second programme of studies in the Faculty of Physics and Mathematics at St Petersburg University. Interestingly, he never completed this programme either. His curriculum records, however, show that he took a wide range of courses from chemistry to ethnology. For the purposes of this book, it is significant that the pioneer physical anthropologist Fëdor Volkov probably was one of his lecturers, or at least Shirokogoroff had to attend his courses without official registration (TsGIA SPb 14-3-59098). Parallel to his studies, he took a position as a cataloguer in the Museum of Anthropology and Ethnology. There he fell under the influence of Vasilii V. Radlov, and Lev IA. Shternberg, who encouraged him to take up the Tungus language for his future studies (see chapter 5). From his later correspondence and memoirs we may guess that Shirokogoroff was dissatisfied with Shternberg's liberal views, which were the result of Shternberg's own political evolution from a member of the terrorist group Narodnaîa volia to a liberal journalist and thinker (Kan 2009). Beyond this, some of his evaluations of Shternberg were properly antiSemitic. Shirokogoroff himself wrote in a letter to Władysław Kotwicz:

That is what interested me in 1911 when I met Shternberg. [...] He was an evolutionist of the provincial-revolutionary school, a comparativist of Frazer's type who was his ideal, and with whom I felt sick, a sentimental judophile (believe me, this was a true complex ${ }^{1}$ !), an idealist seeking

1 In using the term complex Shirokogoroff made the reference to his own forthcoming work on the psychomental complex (1935) where he coined this term as a combination of spiritual, biological, social, and material characteristics of human communities and societies. 
improvement of the "non-Russians" situation in Siberia by means of embracing them into [the ranks of] "progressive humanity", and other things which only interested me in my senior high school years (BN PAU i PAN 4600-7: 55, 6 Feb. 1933).

From this letter, it would appear that Shirokogoroff positioned himself as an opponent of evolutionism and any discussions of progress. His early writings on the "growth and decline" of etnoses seem to imply a collage of small communities changing, expanding or being incorporated into neighbouring groups without a central line of development.

As David G. Anderson documents in chapter 5, Shirokogoroff would date his first intuitions on etnos theory to both his 1912 fieldwork with the Tunguses and Orochens and, partly, to his earlier comparative "statistical" library reading in Paris. However, one could add that his interest in politics was also intertwined with this first fieldwork. His first unpublished ethnographic manuscript on Orochens can be read as an analysis of their political situation in terms of their relationship to the Russian state and their internal clan structure. His letters make clear that the fieldwork itself forced him to decipher the political situation in every particular ulus (district). This fact was not lost on public authorities, who were suspicious of his research. During their third period of fieldwork among the Orochens of Manchuria, Shirokogoroff wrote to Shternberg that he and Elizaveta were perceived by the Chinese as "secret bearers of Russian political influence" (see, for example, SPF ARAN 142-1(1918)68: 140-44v, 4 Aug. 1916). The Shirokogoroffs themselves sometimes requested the support of local military detachments. According to one account, their team looked much like a military expedition, outfitted with horses, uniformed and armed Cossacks, and directed by Shirokogoroff in a gallant leather jacket (Gurevich 1940; see also MRC 3-2-31-6: 357).

During his fieldwork in Manchuria, Sergei documented political protests. In Sakhalian he took photos of a Chinese protest picket and wrote about it in his diary (photos MAE 2639-465-470; TumA 1915/16: 1). In May 1917, while on their way to China for their final Manchurian fieldwork, the Shirokogoroffs were detained and arrested in Rukhlovo station (now Skovorodino in Amurskaîa oblast') under suspicion of being German agents. This incident had a profound impact on Sergei, who wrote about the arrest several times both in letters and in publications. Shirokogoroff would add more detail and more drama 
with each telling of the story. The first person to whom he wrote, from Hǎilāěr, was Shternberg:

The reason for the arrest was, of course, police abuse [of power], which has today become a common thing, in line with the [illegible] understanding of political freedom and the fear of spies who allegedly infested the country and painted themselves in [illegible] the colours of the Romanovs' regime supporters. First we were told that we were [illegible] the Germans. Later, that we were the "acolytes of the old regime", then again that S. Shirokogoroff died in 1915, and it was a German who travelled under his name, and then even that Mrs Shirokogoroff died too, and her place was taken by an Austrian spy. It all looked like a bad joke to me. It was just short of rough justice (SPF ARAN 282-2-319: 21-22v, 13 May 1917).

Later Shirokogoroff would add a biblical tint to the story, presenting himself as a wise man surrounded by chaotic and quite naïve people who were like "lost sheep". Such an updated version of the story he retold in his open and published letter to his colleague Daniel Kulp:

I was arrested together with my wife and a Tungus when travelling, with all my paraphernalia of an ethnological expedition, along the Amur Railway. I was suspected (chiefly physiognomically) of having been a "reactionary". The local Committee of Social Safety (it consisted of twelve members, evidently in an unconscious imitation of Twelve Disciples, gathered among the local "liberal intelligentsia" so much now appreciated abroad) in its general meetings discussed my case, sometimes in my presence. Among other interesting situations, I now want to quote one which happened on the tenth day, or so, of their labour on my case. The president at my trial told me for reconciliation, -

"When you produce us evidence of your real loyalty to us, we will recognize you as good as we are. "I lifted up my eyes to the ceiling and recited:

"God, I thank thee that I am not as other men are." [Luke 18:1]

The president, who evidently was familiar with the Testament, vividly asked me:

"Why?"

"Because, - I replied - I do not want to go together with you into the jail".

As ethnographer, I must confess that my prediction was wrong. In so far as I could gather, most of these unfortunate people physically perished from the hands of both "whites" and "reds" (Shirokogoroff 1932: 33). 
The Shirokogoroffs were rescued thanks to the timely actions of an old friend from Vol'sk. The then-minister of justice of the Provisional Government in Petrograd, Aleksandr F. Kerenskiı̌, sent the following cable:

Dukhnovo station, ${ }^{2}$ East Siberia.

Attn. of the Public Security Committee.

I insist on immediate release of a researcher Shirokogoroff well known to me personally who was commissioned by the Academy of Sciences to do scientific research on its behalf. I request to be personally informed of the forthcoming orders to this effect.

Minister of Justice Kerenskiı (GARF 124-55-338: 2, 30 Apr. 1917).

In all his descriptions of the arrest, Sergei never placed his captors in a political landscape of the Far East. We do not know exactly who they were. The only thing I might presume, they definitely did not sympathise with the monarchy.

The archival records suggest that the Shirokogoroffs' arrest became a turning point in Sergei's life. Before the incident, there is no mention in the correspondence of any thought of leaving Russia nor abandoning his duties at the museum. On the contrary, the field correspondence reads more like a programme for further repeated anthropological, linguistic and museum research. I suppose the arrest itself put him into the awkward position of looking like a sympathiser of the "old regime". The life history of his family suggests the opposite. Nevertheless, his reflections on his arrest - together with the disintegrating political events which surrounded him - encouraged Sergei to choose a more conservative political agenda. From a position of being strictly against political parties of any kind, he seems to have moved to a strong belief in the power of pure science to reveal the internal motions of an etnos/ narod (people).

Following their release, the Shirokogoroffs continued on to Petrograd and then to Elizaveta's family retreat in the far south in Ekaterinodar (Krasnodar). During their stay there, the couple tried to make a difficult decision on whether or not remain in Petrograd, or to avoid the building political instability by emigrating to the east or to the west. The correspondence contained in the archives sheds light on

2 This is a misprint in the original. The Shirokogoroffs were arrested in Rukhlovo station. See above. 
Sergei's political thinking. In August 1917, Sergei wrote a series of letters to Radlov asking his opinion as to what to do. He also met Shternberg at the nearby resort town of Essentuki and discussed with him their future plans (SPF ARAN 282-2-319: 23-24v). These weeks were a real test for the Shirokogoroffs. In a letter to Radlov, dated 1 August 1917 [OS], Shirokogoroff wrote rather candidly:

we are still living with as little knowledge about our immediate next steps, as before. I and Lev IAkovlevich [Shternberg] have agreed to decide what to do depending on the general political situation. To my mind, there are no clear indications of any certainty yet, and I keep mentally oscillating between [choosing] Petersburg and the Far East (SPF ARAN 142-1(1918)-72: 17).

Shternberg was of two minds. His liberal politics led him to believe that the February Revolution was a special moment in history and exhorted Shirokogoroff to remain in Russia. Radlov, took the opposite position: he urged that the couple travel abroad instead (BN PAU i PAN 46007: 54-57). A month later, in a telegram dated 13 September 1917 [OS], Shirokogoroff demanded that Shternberg make at least some decision about his fate:

[YOUR] DELAYED DECISION ON THE SITUATION MIGHT HAVE UNFAVOURABLE CONSEQUENSES PLEASE INFORM OF [YOUR] ADVICE SOON SHIROKOGOROFF (SPF ARAN 142-1(1918)-71: 44).

Shternberg played a special role in Shirokogoroff's life. He was Shirokogoroff's supervisor, the designer of his first fieldwork (see chapter 5) as well as his close colleague. Undoubtedly, Shirokogoroff thought that the older man had his finger on the pulse of the unfolding revolutionary events in the capital. Unfortunately, we do not know what Shternberg's reply was. I can only speculate that Shternberg, like Radlov, would recommend that Shirokogoroff leave Petrograd. Perhaps he simply did not reply. In any event, upon their return to Petrograd the Shirokogoroffs made a round of all their acquaintances and, apparently, made a decision to go "East".

Prior to their departure on 16 October 1917 [OS] Shirokogoroff paid a visit to the well-known geochemist, philosopher, and close friend of Elizaveta and Sergei's family, Vasiliı I. Vernadskiı̌. The latter's diary contains a very brief note thereof: "An anthropologist S. Shirokogoroff 
visited. A ticket to Peiping" (Vernadskir 1994: 21). A week later, on 23 October 1917 [OS], Shirokogoroff visited Władysław Kotwicz, only two days before the Bolsheviks stormed the Winter Palace (BN PAU i PAN 4600-6: 5).

By May 1918, the Shirokogoroffs were already in Beiping, but they were still unsure of where to go next. On 17 May 1918, Sergei wrote to Shternberg:

In Manchuria and part of Mongolia, as you know, groups opposed to the Bolsheviks were formed, and this adds significant instability to the general situation. Of course, one cannot even think of [undertaking] any research in the area of conflict. From my contacts with the local people in the Ussuri land we gathered that it would have been possible to work there, and intended to depart in early April, but the occupation of Vladivostok and the subsequent migrations of the people destroyed that plan (SPF ARAN 142-1(1918)-72: 22).

Shirokogoroff's opinion of the revolution, as seen from this extract, was rather ambiguous. Despite his later anti-Bolshevik sentiments, at this period of time he places the blame on the opponents of the Bolsheviks for creating instability in the region.

The details of the couple's life during the height of the civil wars from May 1918 to June 1920 remain murky and unclear. Scraps of commentary in various published documents hint at the fact that Shirokogoroff began to develop an expressly anti-Bolshevik view while striking up a close relationship with General Dmitrii Khorvat (Horvath) (1858-1937). General Khorvat, who at the time of the October Revolution directed the Russian-owned Chinese Eastern Railway in Manchuria, refused to accept Soviet power. In late 1917, he formed the Far Eastern Committee for the Defence of the Fatherland based in Harbin, which served as a counter-revolutionary government in the Russian sphere of influence in Manchuria. From 1918-1920 Khorvat became the Supreme Plenipotentiary of the Provisional Siberian government headed by Admiral Kolchak (Smele 2015a: 571). It would seem that Khorvat encouraged Shirokogoroff to work for the White administration in the Russian Far East. Shirokogoroff was hired as a staff member in the Diplomatic Office of the Provisional Government of the Far East (MRC 45-3-9), and in December 1918 he was appointed the head of that office (MRC 45-4-1). 
At about the same time, he joined the Far East Committee located in Vladivostok and Harbin. There he put his name to a welcoming address to Admiral Kolchak upon his visit to Vladivostok (not later than 25 November 1918):

We, members of the Far East Committee located in Vladivostok, sincerely welcome your taking this high and responsible position. We see in this act an accomplishment of the idea of autocracy which alone can put Russia back on the road to its former glory and power, the idea which had been driving all our efforts. From the bottom of our hearts we wish you every success in this hard work to the benefit and glory of our beloved Motherland. Shirokogorov, Zaŭtsev, Usakovskiu, Ratushenko, Bukhman (Zhuravlev 2012: 42, emphasis added.).

Shirokogoroff's relationship with Admiral Kolchak likely also interwove politics and ethnography. The admiral, who had a background in polar exploration, most likely invited Shirokogoroff to his capital in Omsk in June 1919 to help organize a Siberian Studies Institute (1919-1920/1921) (Fominykh 2008). This institute would have brought together many of Shirokogoroff's old acquaintances from St Petersburg and, in particular, his former co-workers from the Commission on Cartography (e.g. Serge I. Rudenko, who was at that time in Tomsk).

Kolchak intended for Shirokogoroff to establish a Far Eastern branch of the institute. In the institute's proposed structure we may see also the influence of the "regionalists" (oblastniki), (Kovaliasshkina 2005) whose ambitions were, as is known, not just the separation of Siberia, but also the attribution to this territory of a special social, cultural, and political meaning. It is interesting that the course which Shirokogoroff himself would later teach in the Far East University was also on Siberian studies. Further, as noted by historians of the Civil War, Vladivostok at the time seemed like a good place to live: the city was buoyed by burgeoning international trade (Smith 1975: 5), and was seen to offer intellectual and economic opportunity.

The Kolchak government fell in 1919 and Vladivostok came under the influence of the pro-Soviet Far Eastern Republic (April 1920-November 1922). This regime then became subject to yet another coup launched by the Merkulov brothers, who created the provisional government of Priamur'e (1921-1922). During this time Shirokogoroff served as a secretary of the local parliament, lectured in ethnography at the Far 
Eastern University, and, according to his own account, honed his skills as an "observer" of political processes.

While firmly based within the Russian Far East up until the end of 1922, Shirokogoroff was still uncertain about where to base his career. He wrote to Franz Boas asking for work in the United States. Boas advised him to remain where he was and "to acknowledge the elementary force which is carrying along the social development of Russia and to make the best of it, trying to develop on the given basis a happier future" (APS Boas Collection 82: 1, Boas to Shirokogoroff, 13 July 1920). Throughout this period, he also remained the Head of Department of the [Physical] Anthropological Division of the Museum of Anthropology and Ethnography. He continued to file regular annual reports to the museum on his activities. In a letter to his life-long friend Kotwicz, he described his life in Vladivostok in this period as a "business trip without end" (bessrochnaîa komandirovka) (BN PAU i PAN 4600-6: 5), suggesting that in at least one part of his mind he still rooted himself in Petrograd's intellectual environment.

It would seem that the feeling was mutual. As late as 28 February 1923, Shternberg invited Shirokogoroff to return to the museum and join the Department of the Evolution of Culture (SPF ARAN 142-1(1923)3: 13-14). There was a material link to Petrograd as well. It seems that in their rush to leave Petrograd on the eve of the October Revolution, most of the Shirokogoroffs' field materials remained in the city. In future letters, Sergei would chafe at the loss of the materials abandoned in the "committee's closet"3 (SPF ARAN 282-2-319: 24-24v). In this important period of his life, where he had to choose between Petrograd and the Russian Far East, Shirokogoroff would publish his first works on etnos theory and his first political pamphlets simultaneously. The region's seething instability seemed to feed into his need to theorize and systematize. It was during this period that the theoretical interplay between politics and ethnography was at its height.

3 Most likely what he had in mind was one of the closets of the RGS Commission for Making the Ethnographic Maps of Russia. Those manuscripts would later find their way to the archives of Dmitrĭ K. Zelenin, probably because Shirokogoroff and Zelenin worked together on the commission. 


\section{Shirokogoroff in Vladivostok: A Lecturer and a Politician}

According to his official biographies, and the introductions to his publications, Shirokogoroff began working at a newly established private Department of History and Philology in Vladivostok in 1918. ${ }^{4}$ $\mathrm{He}$ and his other colleagues were central figures in the establishment of the Far Eastern University in 1920 on the foundation of the Oriental Institute (Vostochny Institut) in Vladivostok. In January 1922 Shirokogoroff moved to the Department of Ethnography in the Oriental Faculty (RGIA DV P-289-2-1573: 26-26v). Initially the University was under control of one of the local governments, Primor'e Zemstvo Government (Primorskaîa oblastnaîa zemskaîa uprava) and later of the Far Eastern Republic.

Shirokogoroff's contribution to the study of Siberian ethnography at the Far Eastern University is well known. It is here that he was first appointed as an adjunct lecturer/professor (privat-dotsent) of ethnography on the strength of his association with the Sorbonne in Paris (RGIA DV P-289-2-1573). He published his widely cited book, entitled Étnos, in 1923. Although published in Shanghai, this work was based on the course of lectures that he gave at the university in 1921-1922 (Shirokogorov 1923). Building on a very brief note that he worked in a Russian publishing house in Shanghai (SPF ARAN 1421(1924)-4: 12), we might assume that Ėtnos was likely published in a publishing house called Sibpress that Shirokogoroff either owned or managed. Further, the first of his signature studies were all published during Shirokogoroff's Vladivostok period. These included his first work on Tungus shamanism (Shirokogorov 1919b), the published field report of his and Elizaveta's Manchurian fieldwork (Shirokogorova 1919), and Sergei's programme for re-organising all Siberian physical anthropological research (Shirokogorov 1919a).

Despite these successes it would seem that Shirokogoroff's academic work did not bring him any income or, as he put it himself, pleasure, unlike his involvement in local political struggles:

4 Initially this department was independent and became part of the Far Eastern University in 1920. 
I had to [...] lecture at [Far Eastern] University. The latter was especially unpleasant since I had to do my unloved job putting to use my lovely knowledge. [They] paid [me] wretchedly and lately very poorly (Shirokogoroff to Shternberg, SPF ARAN 282-2-319: 27v, 4 Dec. 1922).

He also found intellectual life in Vladivostok during that period rather dull:

The energy of all [the scholars in Vladivostok] was spent on finding ways to get paid by various governments, - between 1917 and 1922 alone there were 8 of them!! Seems to be a record? - defending their interests and other similar trivial affairs (Ibid: 26v).

He adapted to his situation by trying to hone his ethnographic skills within the rapidly changing political context. In one of his annual reports to the Museum of Anthropology and Ethnography in Petrograd, Shirokogoroff described himself to his museum superiors as a politician who ethnographically observed the life of the "civilized peoples". He felt that during times "of political instability the ethnographic characteristics of the peoples and their individual groups became a lot more visible" (SPF ARAN 142-1(1924)-4: 11). The international environment of the city of that time likely encouraged Shirokogoroff to view his thoughts as universal. We may also conclude that Shirokogoroff was perhaps one of the first ethnographers to study the Russian Revolution and the Civil War. He lived on the outskirts of a disintegrating empire and observed all these events with his own eyes. Here he travelled a parallel road to his would-be mentor Shternberg, who also wrote an ethnographic account of the revolution but from the point of view of living at the centre of the collapsing empire (Shternberg 2009).

Between his lectures on Siberian studies and $\dot{E}$ tnos, in March and May of 1921, Shirokogoroff was actively involved with the "Non-Socialist Movement" (NSM) an umbrella group of anti-Bolshevik organisations in the Far East. His activity even inspired the journalist Vsevolod Ivanov (Posadskov 2015) to mention "Shirokogoroff's flannel suit" in passing in a satirical poem about the People's Assembly (Anon. 1921). ${ }^{5}$ It was during this period of time that Shirokogoroff most likely collaborated

5 Apparently, Ivanov was a prototype for the character of Vanîushin from Semënov's novel No Password Required with which I started my article. 
with the Merkulov brothers. Canfield Smith sums up the political debates within non-socialistic movements in the following way:

The right wing of the nonsocialists, to whom the term "nonsocialist" was most generally applied, was hostile to the socialists of all parties. Politically they ranged from dedicated monarchists to conservative republicans, and they had nothing philosophically common with the socialists. They were not as committed to democratic methods as the other nonsocialists and moderate socialists, as their subsequent actions indicated. Like the Communists, they believed the goal justified the means. They could plan a coup with no regrets, and they could take a much more favourable view towards the Japanese because, as long as the Japanese were present, they could enjoy political and economic rights (Smith 1975: 84-5).

Although it remains a little unclear exactly which "wing" Shirokgoroff represented, there are some clues in a series of little-known brochures he published on behalf of the NSM. These brochures, all published in the same year, paint a picture of a man with many hats: a politician, a teacher, and an ethnographer. In one brochure, "The Goals of the NSM", he develops the idea of the "bankruptcy of political parties" by concluding that "parties will never be able to rule a state, no matter how good their programs and their members could be" (Shirokogorov 1922c: 5). At the end of his pamphlet, he offered up two solutions to the raging chaos: either a parliamentary monarchy with a constitution, as in Great Britain, or a monarchy supported by institutions of local self-government (zemstvo). These brochures move on to elaborate his somewhat unorthodox concept of a "national movement", while another self-published brochure promoted his idea of a self-regulating etnos (Shirokogorov 1922a).

It should be noted that Shirokogoroff's political brochures outlined a non-standard definition of the nation. He describes a vision of an "allstate [obshchegosudarstvennyi] or national movement uniting the entire population [of those] not belonging to any political party" (Shirokogorov 1922d: 6). Here he believed that this nation of people rejecting political parties would be represented by a type of non-socialist parliament:

Those elected by the people, who are currently working together [in a coalition] of different organizations, have already recognized their national misfortune. They have taken upon themselves the heavy weight 
of public service. They, the representatives of the population themselves, who are in fact part of the population, have come to a national awareness. They have escaped the clutches of the political parties. They are a real people [podlinnyı̆ narod] (Shirokogorov 1922d: 13).

In a second pamphlet, "Have We Made a Mistake?" Shirokogorov develops a principle of popular rule (narodopravstvo) that he associated with the work of the People's Assembly of which he had been a part (Shirokogorov 1922c: 4, 5). Shirokogorov saw the "people" being animated by a popular "will" (volia) which manifested itself within a broad "national" movement (Shirokogorov 1922d: 6). It might be possible to read into his interest in reading and representing the "popular will" a kind of Rousseauian "general will" with its sometimes authoritarian connotations (N. Knight, pers. comm., 11 Jun. 2018). Shirokogoroff's model of representing the "popular will" through an assembly is mirrored in his early writing on Tungus shamanism, where he represents the "elected shaman" as a kind of diplomat who negotiates between people and spirits (Shirokogorov 1919b). He most likely was alluding to this work when he wrote to Shternberg describing his role in the People's Assembly as that of a shaman.

Although it is difficult to read much into the pamphlets, the tone of which is primarily critical of the Bolshevik coup, there is a strong hint that his "real" people are a self-organizing coalition much like his etnos was a self-regulating group identity:

The wishes of the population themselves, the healthy instinct of the people themselves that comes to a state of mental equilibrium is the basis of this [non-socialistic] movement. This new movement is a national movement which has discarded political parties and is shaped in an absolutely different way (Shirokogoroff 1922c: 13).

The same year, he published yet another booklet on Russia's international position that seems to be a summary of his critical reflections on the annotations that he made on Karl Marx and other philosophers when he studied in the National Library in Paris. In this pamphlet, there were only three countries on his geopolitical map: Germany, the United States and Russia. Here he reiterated his view that political parties are malign entities, stating that the "division into parties in Russia is based, mostly, on psychology and the level 
of education of the people, rather than on the dominance of a certain idea as a purely logical concept" (Shirokogorov 1922b: 32). Elsewhere in his booklet he spoke about yet another threat: the appearance of a "people-less internationalism" (beznarodny̆ internatsionalizm) (Ibid: 23). He understood Russia's fate in this regard as a rather simple development:

Imperial Power under the effect of new trends, and the changes in the economic and political structure of the state, had degraded into a party organization. That was the state Russia was in when the war started. And even though the rise of national sentiment in 1914 had seemingly smoothed out the differences, the people's cold relations with the government stayed unchanged and all the warmness of the national feeling was transferred onto the army (Ibid: 33; See also Shirokogorov 1922c: 13).

As an opponent of political parties and the idea of classes Shirokogoroff put forward the notion of "the people" as a social unit and the main driving force of social life. Sometimes he elaborated on this picture with the concept of races, which were degenerating, parasitical, or new (Shirokogorov 1922b: 50). These ideas seem to shadow his ideas of assimilation (or as he called it later "amalgamation"), which had puzzled him during his first ethnographic fieldwork in Siberia (see chapter 5).

His enthusiasm for the NSM, and the People's Assembly, however, did not last long. By the autumn of 1921 a new conflict had erupted. Ivanov publicly criticized the NSM's leadership - which included Shirokogoroff among others - by saying: "Your Council has become a sovdep, ${ }^{6}$ a source of devastation and collapse, an assembly of some actions and speeches driven exclusively by your petty egos" (qtd. in Posadskov 2015: 47). The exact reason for this conflict remains unknown, but it clearly incited harsh sentiments. In the archives of the Museum of Russian Culture in San Francisco there are several leaflets from that time (Fig. 6.5), one of which was probably related to the events described by Ivanov.

6 An abbreviation for the Soviet of Deputies, which carries the pejorative meaning of an amoral and formal adherence to party politics. 


\section{БOЙKOTЬ ПРЕДATEMGM.}

Запомните, запечатлыйте, руеекіе траждане липа и имена иреетунниковь, предателей Родины, разрунитеней русеваго дівла.

ВоТь ОНИ:

\section{Густовъ, Циитрій И.} Андрушкевичъ, Николай А., Бопдыревъ, генералъ, Пихойдовъ, Константигь Т., Uирокогоровь, Сергый м., Зибзеевъ, Николай, Ивановъ, Василій Ф., Опенкнъ, Паведъ В., Донченко, Ваєитій II.,

Воть өни, гжавпие руюоводители бунта, сбивтіе еъ толку вюяздвпихь въ нонитику военныхь.

Әтө өни раврушили ночти вее то, что было едћланө въ течении гөда, әто они. кањь гнуетные убійцы вонэили ножъ въ спину нангего Края и изстрадавнейея Родинь.

Спроеите өтидда явилиеь әти мерзавцы не умбюmiе создавать и могупіе разруиать.

Велкій шз Вась, граждане, отныны долженьлрезирать әтихь ирестунниковъ, осквернитоя тоть, кто подаеть руку әтимъ негодяямъ.

Не подходите къ нимъ, гойте ихъ отовеюду, не заранац̆есь ихъ преступленіями.

Посмотрите, вюҺдь на пихъ ПЕИАТЬ КАИНА.

Сторонитееь әтихь прокаженныхъ !!!

\section{ATPIOT M.}

Fig. 6.5 Political leaflet. Vladivostok [1921] (MRC: unnumbered). () Museum of Russian Culture, San Francisco, California 
The leaflet reads:

Boycott the traitors.

Remember, impress, Russian citizens, the faces and names of these criminals, the traitors to the Motherland, the destroyers of the Russian cause.

HERE THEY ARE:

[5] Shirokogorov, Sergei M.

Here they are the main leaders of the riot, who confused the military engaged in politics.

They themselves destroyed almost everything that has been accomplished during the year. They themselves are the vilest killers who stabbed a knife in the back of our Land [Kră ] and the suffering Motherland.

One may ask where did these bastards come from, who cannot create and can destroy.

Every one of you, citizens, should henceforth despise these criminals. Anyone who assists these scoundrels will be defiled.

Do not approach them, turn them out everywhere, do not become infected with their crimes.

Look, they have the MARK OF CAIN on them, after all.

Stay away from these lepers!

PATRIOTS.

The intensity of the anger that this incident generated led to Shirokogoroff being fired from the university on 26 October 1922 (RGIA DV P-289-21573: 16-16v, 18v). In fear of the political persecution they might suffer, he and his wife were forced to leave Vladivostok for Shanghai. 


\section{The Chinese Years: In the Shadow of Imperial Japan and Nazi Germany}

The political instability in Vladivostok, and Shirokogoroff's own unsuccessful political debut, seems to have driven the couple to leave Russia. They travelled first to Japan, ${ }^{7}$ before setting on China as a place where they might enjoy some stability. They ended up living in China, and its various shifting nationalist and Japanese-occupied fragments, for the rest of their lives - even if that may not have been their original intention. Largely, they traded one unstable political context for another. This move would have a great influence on Shirokogoroff's work and career. In this equally shifting political landscape he would compose all of the published works for which he is best known. Substantively, he shifted his research to communities within China; he also switched from using Russian to English as his main language of publication (BN PAU i PAN 4600-6: 11v).

Shirokogoroff's tether to St Petersburg was broken in 1923 when he was dismissed from his position as head of the Department of Physical Anthropology at the museum. However, while based in China he continued to expand his network. He started active collaborations with foreigners such as the sociologist Daniel Kulp, who studied the Chinese peasantry (Shirokogoroff 1932), and the medical doctor Vivia B. Appleton, with whom he conducted anthropometric measurements on Chinese children (Appleton 1976; Shirokogoroff and Appleton 1924). He also reached out to scholars around the globe through correspondence. We have found more than 100 letters that represent this period of his life between 1923 and 1939. In these letters he often presents himself as a key person who could provide foreign scholars access to the Chinese field.

In China he was constantly "migrating" from university to university on a number of short-term contracts. His failure to secure a permanent position might be put down to his personality, which many contemporaries remember as being acerbic and antagonistic, or it might be put down to the instability of the times. He began his Chinese career by giving lectures informally, or by contract, for a range of scholarly

7 The choice of the country was most probably based on his personal involvement in the diplomatic relations between Kolchak, Khorvat, the Merkulovs and the Japanese. 
associations in Shanghai between 1922 and 1926. During that period of time, he translated and published a summary of his etnos theory in Ethnical Unit and Millieu (Shirokogoroff 1924), which was printed in booklet form by Edward Evans and Sons, a popular publishing house in Shanghai at that time (Chen 2013). While in Shanghai he completed a number of works on Tungus shamanism, physical anthropology, kinship studies, and even some memoirs about his heroic Zabaŭkal and Manchurian expeditions. By 1924-1925 he had become involved in Chinese academic life through his anthropometric fieldwork in eastern China and Kwangtung Province.

Thereafter Shirokogoroff worked in the south at the core of the new nationalist institutions formed after the first Chinese revolution. He worked for short periods at the University of Amoy (Xiàmén) (19261928), the Institute of History and Philology at Sun Yat Sen University in Canton (Guăngzhōu) (1927-1930), as well as the renowned Academia Sinica (1928-1930). Often his appointments overlapped. His tenure at Academia Sinica was arguably the pinnacle of his career. It was there that he attempted to set up an anthropometric laboratory designed to work in the service of the new nationalist government to help define the contours of the Chinese nation (Anderson and Arzyutov forthcoming).

Here he set out upon, but did not complete, a challenging field expedition to the Yi (Lolo) nationality in Yunnan. This failed fieldwork eventually led to controversy, which ended with him being fired from the Academia Sinica on the grounds that foreign scholars could not adequately function within and understand the Chinese situation (Liú Xiăoyún 2007b; Krîukov 2007). However, he left a lasting contribution to Chinese science in Canton through the training of a young fieldworker, Yáng Chéngzhì, who would go on to become one of the foremost Chinese specialists on the Yi people and a key figure in the development of Chinese anthropology (Guldin 1994: 50-55; Liú Xiăoyún 2007a).

Although Shirokogoroff angered people he also had good friends. His patrons managed to find him a position in Beiping at the Tsing Hua University where he worked from 1930 to 1937. An interesting short memoir by Frances Hsu captures the testy, international setting of Beiping during this period:

Western scholars also brought their Chinese co-workers and students actively into European academic quarrels. During many months between 
1935 and 1936 Professor Radcliffe-Brown resided in Yenching University. Father Wilhelm Schmidt entrenched himself behind the castle-like structures of the Catholic University of Peking, while Professor S. M. Shirokogoroff was on the faculty of Tsing Hua University, but these men could not be persuaded to see each other. Radcliffe-Brown lectured to one group of students on "Synchronic and Diachronic Study of Chinese Villages", Schmidt impressed on a different group of students the basic ideas of 'primary and secondary cultures' as well as his theory of "All Father" or one universal god, while Shirokogoroff pounded up and down the platform before a third group on his theory of Ethnos or the "Psycho-mental Complex" of a racial group (Hsu 1944: 13-14).

It would be in nationalist Beiping where he completed what came to be his defining work: The Psychomental Complex of the Tungus (Shirokogoroff 1935). He also trained another young student, Fèi Xiàotōng (1910-2005), who would later become the central figure in the development of nationality studies in the People's Republic. The young Fèi, with his first wife, published their own field observations from Guangxi wherein he concluded that the Yaos were crafting their own identities through the reflexive and biosocial "ethnical unit" that Shirokogoroff propounded (Leibold 2007: 132; Fèi 1999: 468-69). Late in his life, Fèi would credit Shirokogoroff for providing a key inspiration in his search for "unity in diversity" (Wang 2010; Fèi 1994) (see also chapter 5) (see Fig. 6.6).

Shirokogoroff was fired from Tsing Hua for participating in a students' demonstration that may have been related to the Japanese occupation of the city (TumA 109). It is significant that the Shirokogoroffs chose not to evacuate from Beiping after the Japanese occupation in 1937. Instead, Sergei found a job at the Catholic FuJen University (1937-1939). Controversially, during this period he intensified his links with Japanese scholars, who were keen to use ethnography, and in particular ethnographic descriptions of religious confessions, to aid in designing institutions for occupied Manchuria (Duara 2004). This led him to curtail his correspondence with Chinese colleagues to the south in nationalist China.

While living in Beiping, Shirokogoroff even fell out of contact with his Russian relatives. He wrote his last letter to his uncle Ivan Ivanovich Shirokogorov in 1932 (SPF ARAN 820-3-879) when he sent him his newly published brochure, Ethnological and Linguistic Aspects of the UralAltaic Hypothesis (Shirokogoroff 1931). 


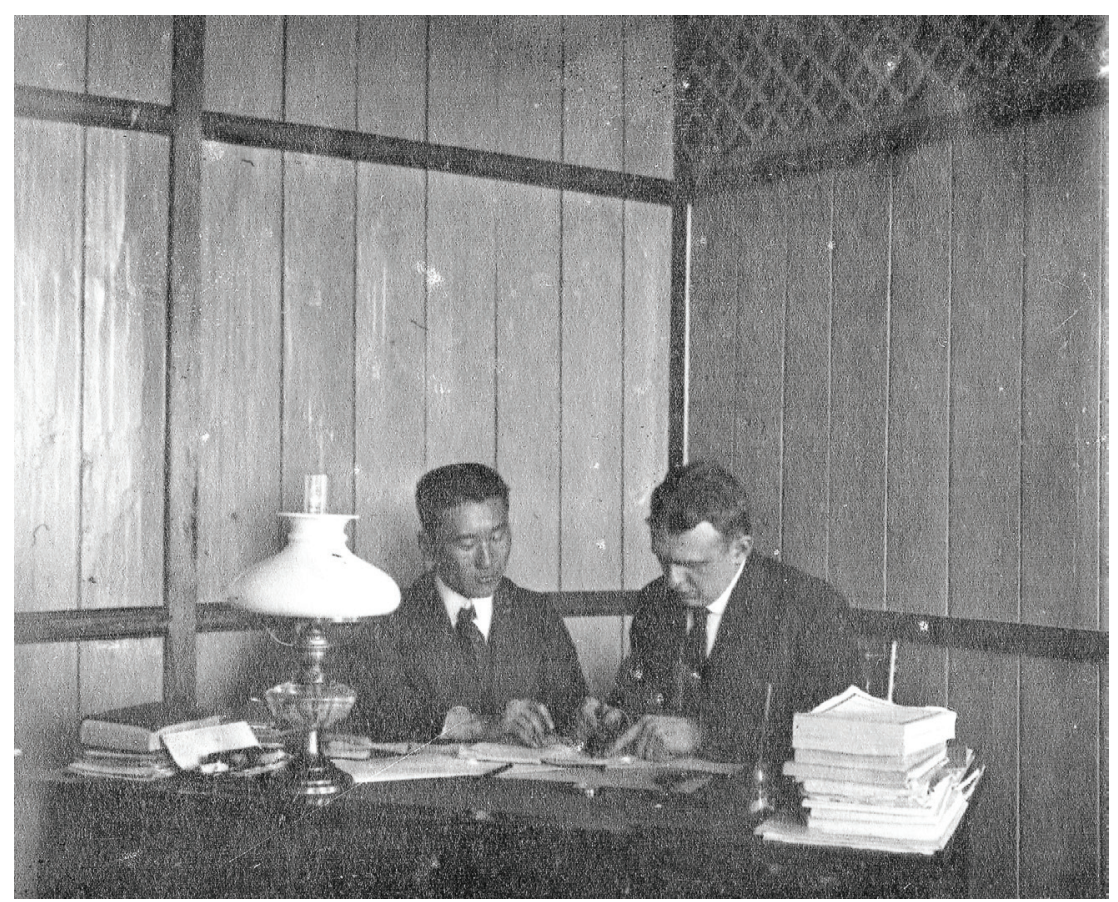

Fig. 6.6 Sergei Shirokogoroff working with one of his students, China (EVR)

Sergei Shirokogoroff died in 1939 during the occupation and was buried in the Russian cemetery around the Uspenskaia Church (TumA 183), now part of the Russian embassy complex in Běijing. After his death, his widow Elizaveta turned to Japan as a place where Sergei's manuscripts might be published. She tried, and failed, to publish Sergei's now lost two-volume book-length manuscript on etnos theory, but did manage to publish under his name a Tungus dictionary that she herself transcribed and wrote by hand (Shirokogoroff 1944).

While in Canton and Beiping, Shirokogoroff started an active, not to say aggressive, promotion of his ideas, circulating self-published brochures and seeking to ingratiate himself with like-minded people in various corners of the world. Not all of his correspondents shared his ideas and nor were they ready to communicate with him, but some of them promoted his ideas in Great Britain and Europe. One of the "principal defenders" of Shirokogoroff's ideas in London in the mid1920s was Arthur Keith (BN PAU i PAN 4600-6: 65-66). Shirokogoroff valued Keith's opinion highly, in spite of the fact that Keith never cited 
him in his book, entitled Ethnos; or, the Problem of Race Considered from a New Point of View (Keith 1931) (BN PAU i PAN 4600-7: 32-32v).

But international contacts helped Shirokogoroff made his own career in China. For example, in 1927, as part of his last-ditch effort to keep his job, Shirokogoroff cited his collaboration with Keith to the president of the Academia Sinica as evidence of his international reputation (SPF ARAN 820-3-880: 40-43; BN PAU i PAN 4600-6: 64-66; AS Yuan 46-26). Suffering from a lack of understanding from the majority of his Russian colleagues (Chepurkovskiî 1938: 7-9), Keith's interest encouraged Shirokogoroff to further promote his concepts, including etnos and the psychomental complex.

It is difficult to gauge Shirokogoroff's reaction to the disintegrating political situation in China. Only a few letters hinted at his ongoing reflections on the October revolution and political chaos. In general, in this period of his life he did not intervene in Chinese domestic politics, but wrote to his confidants and even made public speeches, in Russian, about political affairs in the Soviet Union. His day-to-day scientific work remained in English. Thus, in one of his first letters from China, addressed to Kotwicz on 14 August 1924, Shirokogoroff wrote:

The name I'd like to give to all this [the revolution] is ethnic disintegration, and it's even hard to imagine how deeply it has affected the world (BN PAU i PAN 4600/6: 9-9v).

Another startling example is an article on Tungus linguistics, which was first published many decades after his death (Shirokogoroff and Inoue 1991 [1939]), wherein he made scathing criticisms of how Soviet policies had been affecting Tungus Evenki people.

The most intriguing moment in Shirokogoroff's intellectual and political biography is the sabbatical year he spent in Nazi-controlled Germany (1935-1936). Although we still know very little about his contacts there or what he was working on at the time, we have reconstructed some scattered episodes that shed light on his political and anthropological reflections. Donald Tumasonis kindly shared with us some of the letters in which Karl H. Menges, the German linguist, recollected his meeting with Shirokogoroff in Germany. In one of the letters (3 March 1987) Menges wrote that during their meeting in Berlin in the spring of 1936, Shirokogoroff shared with him his desire to leave 
China. Menges, on his part, rather bluntly told him that Germany was far from the best place to move to, primarily because of the "new state religion" (i.e. Nazism), and recommended that he go to the United States instead.

Ivan I. Gapanovich, a fellow Russian émigré living with him in Beiping, paints a picture of a Shirokogoroff as a German patriot:

Political opponents jokingly called Shirokogoroff Breitberg, but there were some grounds for this nickname. His Russian name sounds as if it were translated from German and he studied at IUr'ev University, ${ }^{8}$ where the German influence was strong. Further, in his appearance and manners there also was something German. He did not disapprove of Hitler and said that the latter did well for Germany, but found that Hitler himself was a rather ignorant person, and his race theory unsound. However, I do not have any facts confirming that he was a "German". Maybe [he was] second generation [German] (TumA 183).

What was Shirokogoroff's intention in visiting Germany during this difficult time? Was he hoping to move there? It is impossible to answer these questions. His German sabbatical gave him an opportunity to meet some of his correspondents in person and to promote his etnos theory. During his German trip Shirokogoroff came into contact with another British scholar - perhaps one of the most controversial British anthropologists, George H. L. F. Pitt Rivers (1890-1966), infamous for his promotion of racial eugenics and his interest in the Nazi regime (Hart 2015). On 14 November 1935 Shirokogoroff sent him a letter from Berlin, writing the following:

All these years I was following the development of your important work in connection with the "population problem" and your shifting to the practical problem of ethnogenics.

[...] In so far as I can see from what you have published within recent years, a practical application of our knowledge of the population problem occupies you more than anything else. I am also interested in this aspect of the problem, but even now it is questionable, at least for myself, when we were "practically acting" and when we bring up a theoretical justification of our "acting", whether we are merely "functioning" in a certain ethnical body, or we are really consciously "directing" the process? (Chu.Cam PIRI 22/3, emphasis added).

8 This claim that Shirokogoroff studied at IUUr'ev University seems to be incorrect. 
Even this short excerpt from his letter shows some desire on Shirokogoroff's part to apply his theoretical ideas to practical ends.

After the Shirokogoroffs' return to China, Sergei began promoting his work with renewed energy. He published in French and German translations of his earlier articles on etnos theory, originally written between 1919 and 1923 (Shirokogoroff 1937, 1936). While Pitt Rivers was citing Shirokogoroff's name in an attempt to build a eugenics programme within the International Union for the Scientific Study of Populations (Chu.Cam PIRI 11/2), in one of his last public speeches Shirokogoroff spoke to the importance of being able to translate one's ideas into practice:

but it is not enough to come up with an idea, to devise an ideal system - it is necessary to bring it in action, only then will it come to life (Shirokogorov 1938a: xvi, emphasis added).

That speech was made on the occasion of the 325th anniversary of the House of Romanov (Shirokogorov 1938a, 1938b). It was held in the so-called "Russian House" in Beiping - a centre of Russian expatriate life in the Chinese capital. This speech may be considered Shirokogoroff's last major political address and political publication (Speshnev 2004: 125-43). It is important to note that at that time Shirokogoroff was a member of the Beiping group of the Russian anti-communist committee (Fig. 6.7), which was headquartered in Tientsin (Tiānjīn), but also had branches in Beiping, Kalgan (Zhāngjiākǒu), Qingdao, and Cheefoo (Yāntái). This organization was a successor to the Russian nationalistic organizations in China, including the so-called Russian national community (Khisamutdinov 1999). At a time when the Soviet politicians supported anti-Japanese propaganda, the Russian emigrants in China sympathized with the "new order" in Asia and persisted in their commitment to the fight against Bolshevism, sometimes confusing them with the anti-American propaganda. ${ }^{9}$

Shirokogoroff spoke of his vision of history as a merger of power and the people into a single whole, an entity that should be responsible for all political actions. It is the people (or etnos in his anthropological

9 Among other people of "The Beiping anti-communist committee" in Figure 6.7, there is General Sergeǐ N. Rozanov (1869-1937), who was a right-hand man of Admiral Kolchak in Vladivostok. As Canfield Smith writes, his militaristic regime in Vladivostok was actively supported by the Japanese (Smith 1975: 12). 


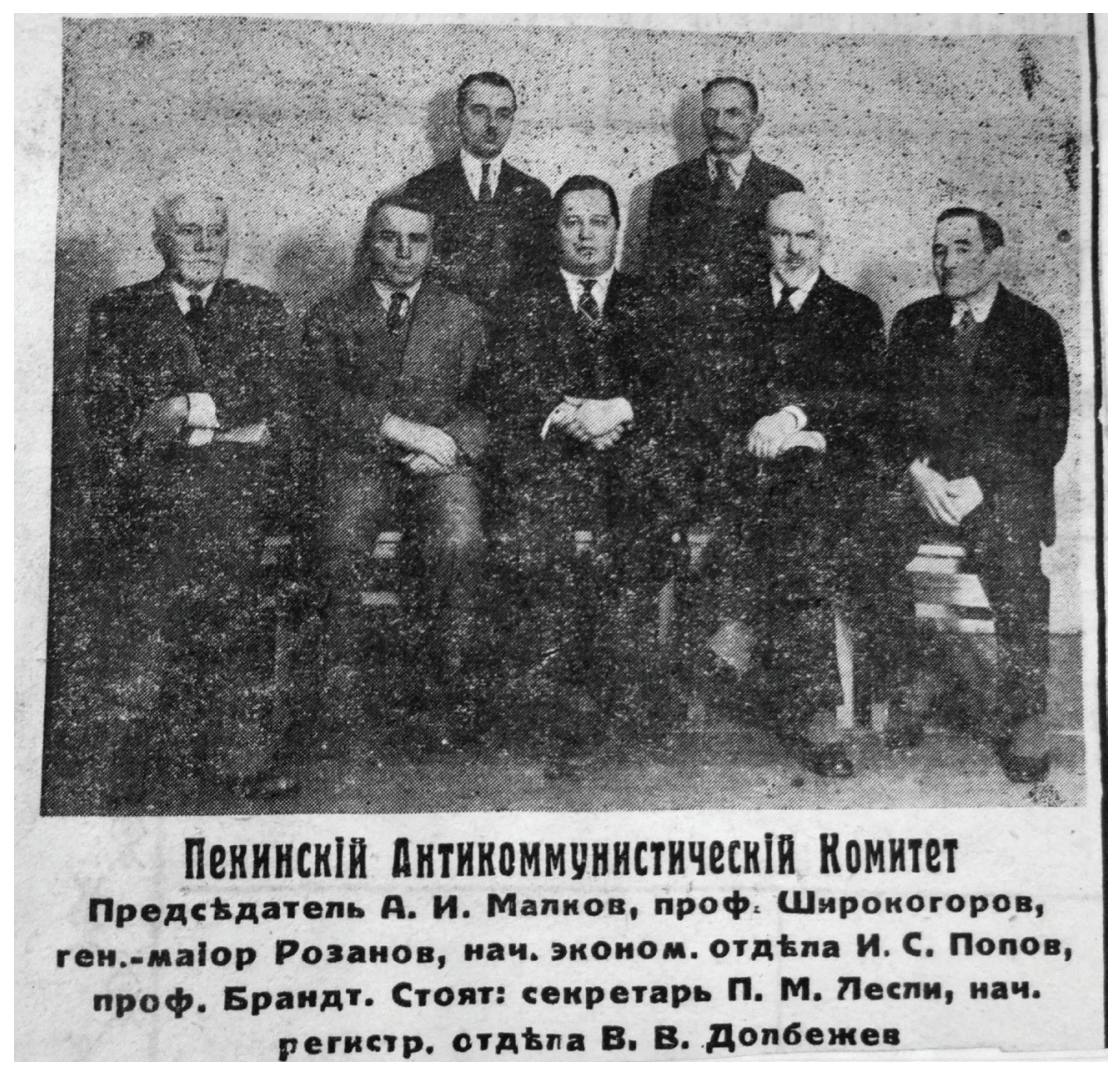

Fig. 6.7 The Beiping anti-communist committee. Shirokogoroff sits second from the right. From Ivan I. Serebrennikov's collection (HILA 1A/5: 40).

(C) Hoover Institution Library and Archives, Stanford University, California

texts) that for him represented a vital force, and at the very end of his Russian House speech he spoke about the "individuality of the peoples", which he saw as having been stable inside the Romanov's empire, primarily owing to the system of hereditary transfer of power. Ironically, it represented his imaginative returning to his Vladivostok years and his personal desire to establish an ideal order composed of etnoses and nations, hopefully dispelling the political chaos around him.

\section{Order out of Chaos}

Having made a decision to go to Vladivostok instead of staying in revolutionary Petrograd, Shirokogoroff became part of the unstable far eastern political landscape. The actual absence of any borders, as well 
as of the state itself, turned the Far East into a peculiar space produced by the flows of people, armies, and ships from many countries. It is well-known that the Japanese, the Chinese, the American, and the Russian forces were all involved in local politics in various degrees, turning the territory into not a "slightly complicated door", as the French anthropologist Grégory Delaplace (2013) put it referring to the contemporary Russian-Chinese-Mongolian border, but rather into a wide-open door without any locks or keys.

Vladivostok and Blagoveshchensk were the centres of gravity for many intellectuals from the European part of Russia. On the one hand, since the beginning of the nineteenth century, that territory had been historically part of the system of the forced relocation of Russian intellectuals. However, many of these people stayed in the area, where they married and had children. This created what to an outsider appeared to be a vivid intellectual life on the outskirts of the empire. On the other hand, the political chaos of the 1920s forced people to look for freedom, and then, after they found it for some time, they went back in their minds to the restoration of the monarchy and the re-establishment of the new/old political order.

In that sense, Shirokogoroff is a good example of such an intellectual, one who converted his "provincialism" into an ideological weapon in both his academic research and politics. His etnos and the diagrams he sketched on his university blackboard illustrating the structure of ethnology, along with his slogans of "non-partied national movement" and "real people", which he uttered at political meetings, created a type of equilibrium in his thought. This stability reflected the way he himself balanced between different political forces in the region. Thus, as I pointed out above, he worked both for the Far East University, which collaborated with the Soviet-supporting Far Eastern Republic, and at the People's Assembly, which was radically anti-Socialist. In China, Shirokogoroff developed his anti-Soviet political agenda further, putting himself on the right wing of the local political landscape. His sense of isolation combined with his unrealised dream to work in a major scientific centre probably made him less sensitive to the dramatic political changes in countries outside his rather small world.

In this particular context, Shirokogoroff's desire to fulfil his academic plans and political ideas blossomed. At that time, he was already the 
author of many books and was just finishing his magnum opus, "Big Etnos" (or Ethnology in two volumes). His works and name were known to many researchers internationally, but it would seem he was more of a pen pal for them than a colleague. His still-poorly-understood visit to Nazi Germany, and the active correspondence he began there with racialists like Pitt Rivers, suggest that he would have liked to have seen his ideas like etnos and psychomental complex implemented politically. He felt that the ideas he developed at the margins of empire should now be employed at the centre.

The stories of Shirokogoroff and those of many other intellectuals of that time reflect the lives of those who lived at the borders of empire as much as they represent alternative concepts of popular rule or ethnicity. They are the works of emigrants who, in their thinking, tried to find the imagined centre of the imperial political landscape via the categories of nationality and ethnicity (see chapters 2, 3 and 4). The geographic and intellectual localization of the theory made its biography interesting not only for the history of anthropological thought, but also for the understanding of political instability as a condition for the development of social theories. Placed right in the middle of the chaotic present and sharing the strong anti-tsarist feelings, the early Soviet ethnographers "made up lists of nationalities for all three censuses using their own experience for the creation of order from chaos and for the creation of a new order of definitions" (Hirsch 1997: 251, emphasis added). This wording was strangely reminiscent of the discussions in the Russian Geographical Society's Commission for Making Ethnographic Maps of Russia of which the central figure of this article - Sergei Mikhailovich Shirokogoroff - was also an active participant. It is quite amazing that, some time after, his ideas (and not only his) were incorporated as quite acceptable by Soviet ethnography - contrary to all the logic of history. 


\section{Published References}

Anderson, D. G., and D. Arzyutov. Forthcoming. 'The Etnos Archipelago: Serger M. Shirokogoroff and the Life History of a Controversial Anthropological Concept', Current Anthropology.

Anon. 1921. Vechernîâa gazeta 14 Sep. 1921.

Appleton, V. B. 1976. A Doctor's Letters from China Fifty Years Ago (Honolulu, HI: [no pub.]).

Chen, L. 2013. 'The Switched-On City', Global Times, 30 Jan. 2013.

Chepurkovskiü, E. M. 1938. Na zadvorkakh i okolo dvorÉsov. Épizody iz zhizni $i$ mysli trekh russkikh studentov, izlozhennye poslednim iz nikh (Tianjin: A. I. Serebriannikov i K.).

Chirokogorov, I. I. 1909. Rapport sur une mission scientifique à Paris (à l'Institut Pasteur) (Iuriev: [no pub.]).

Delaplace, G. 2013. 'A Slightly Complicated Door: The Ethnography and Conceptualisation of North Asian Borders', in Frontier Encounters: Knowledge and Practice at the Russian, Chinese and Mongolian Border, ed. by F. Billé, G. Delaplace, and C. Humphrey (Cambridge: Open Book Publishers), 1-18, https://www.openbookpublishers.com/product/139; https://doi. org/10.11647/OBP.0026

Duara, P. 2004. Sovereignty and Authenticity: Manchukuo and the East Asian Modern (Oxford: Rowman \& Littlefield).

Fèi Xiàotōng. 1994. 'Cóng shǐ lù guó lăoshī xué tǐzhí rénlèi xué', Běijīng dàxué xuébào: Zhéxué shèhuì kēxué băn (5): 13-22.

Fominykh, S. F., ed. 2008. Zhurnaly zasedaniŭ soveta Instituta issledovaniza Sibiri (13 noîabrîa 1919 g. - 16 sentiâbrîa 1920 g.) (Tomsk: Izdatel'stvo TGU).

Guldin, G. E. 1994. The Saga of Anthropology in China: From Malinowski to Moscow to Mao (London: Sharpe).

Gurevich, B. B. 1940. 'Svetloŭ pamîati prof. S. M. Shirokogorova', Zarîa 19 Nov. 1940: 4.

Hart, B. W. 2015. George Pitt-Rivers and the Nazis (London: Bloomsbury).

Hirsch, F. 1997. 'The Soviet Union as a Work in Progress: Ethnographers and the Category of Nationality in the 1926, 1937, and 1939 Censuses', Slavic Review 56 (2): 251-78.

Hsu, F. L. 1944. 'Sociological research in China', Quarterly Bulletin of Chinese Bibliography (ser. 2) 4 (1-4): 12-26.

Kan, S. 2009. Lev Shternberg: Anthropologist, Russian Socialist, Jewish Activist (Lincoln, NE: University of Nebraska Press). 
Keith, S. A. 1931. Ethnos, or the Problem of Race Considered From a New Point of View (London: Kegan Paul).

Kerensky, A. F. 1965. The Kerensky Memoirs: Russia and History's Turning Point (London: Cassell).

Khisamutdinov, A. A. 1999. 'Russkie v Kitae. Tîan'tszin'skaîa vetv' èmigrafsii' Problemy dal'nego Vostoka 2: 118-22.

Kovalîashkina, E. P. 2005. Inorodcheskiŭ vopros v Sibiri: kontseptsii gosudarstvenno politiki i oblastnicheskẫâ mysl' (Tomsk: Izdatel'stvo Tomskogo universiteta).

Krîukov, M. V. 2007. 'S. M. Shirokogorov i IUUn'nan'skaîa èkspeditsiîa 1928 g. ', in Problemy obshchĕ i regional'noŭ ètnografii (k 75-letiūu A. M. Reshetova): Sbornik statel̆, ed. by E. V. Ivanova (St Peterburg: MAĖ RAN), 93-109.

Lîakhov, D. A. 2013. Nebol'shevistskie modeli politicheskogo ustroŭstva Dal'nego Vostoka Rossii (dekabr' 1919 g.-oktîabr' 1922 g.) (unpublished doctoral dissertation, Far Eastern State University, Vladivostok).

Liú Xiăoyún. 2007a. 'Shǐ lù guó duì zhōngguó zăoqí rénlèi xué de yǐngxiăng', Zhōngnán mínzú dàxué xuébào: Rénwén shèhuì kēxué băn 27 (3): 10-14.

—. 2007b. 'Zhī háng liăng xiāng nán: Shǐ lù guó yúnnán diàochá shìjiàn tànxī', Xuéshù tànsuǒ 4: 112-17.

Papillault, G. 1908. 'L'anthropologie est-elle une science unique?', Revue de l'ecole d'anthropologie 18 (April): 117-32.

Posadskov, A. L. 2015. 'Pisatel' V. N. Ivanov vo glave izdatel'skogo dela vremennogo Priamurskogo pravitel'stva (1921-1922 gg.)’, Gumanitarnye nauki v Sibiri 3: 44-9.

Reshetov, A. M. 2001. 'Peterburgskiı̌ period zhizni i deîatel'nosti S. M. Shirokogorova', in Izbrannye raboty $i$ materialy. Kniga 1, ed. by A. M. Kuzentsov (Vladivostok: Izd. DV univ.), 6-31.

Semënov, I. S. 1994 [1966]. 'Parol' ne nuzhen', in Sobranie Sochineniŭ, by I. S. Semënov (Moscow: KUBK-a), 289-590.

Shirokogoroff, S. M. 1924. Ethnical Unit and Milieu: A Summary of the Ethnos (Shanghai: E. Evans and Sons).

- 1931. Ethnological and Linguistic Aspects of the Ural-Altaic Hypothesis (Peiping: Commercial Press).

—. 1932. Letter to Professor Dr D. H. Kulp, 30 July 1932 (Peiping: [no pub.]).

- 1935. Psychomental Complex of the Tungus (London: Kegan Paul).

—. 1936. 'La Théorie de l'Ethnos et sa place dans le système des sciences anthropologiques', L'Ethnographie. Nouv. Ser. 32: 85-115.

—. 1937. 'Ethnographie und Ethnologie', Archiv für Anthropologie 52: 1-7.

-. 1944. A Tungus Dictionary: Tungus-Russian and Russian-Tungus Photogravured from the Manuscripts (Tokyo: Minzokugaru Kyokai). 
Shirokogoroff, S. M. and V. B. Appleton. 1924. 'Growth of Chinese', China Medical Journal 38 (5): 400-13.

Shirokogoroff, S. M. and K. Inoue. 1991 [1939]. 'Tungus Literary Language', Asian Folklore Studies 50: 35-66.

Shirokogorov, S. M. 1919a. 'O metodakh razrabotki antropologicheskikh materialov', Uchenye zapiski istoriko-filologicheskogo fakul'teta v Vladivostoke 1 (2): 3-20.

—. 1919b. 'Opyt issledovaniîa osnov shamanstva u tungusov', Uchenye zapiski istoriko-filologicheskogo fakul'teta v Vladivostoke 1: 47-108.

—. 1922a. Mesto ètnografii sredi nauk i klassifikatsita ètnosov (Vladivostok: izd "Svobodnaîa Rossiîa").

—. 1922b. Mezhdunardnoe polozhenie Rossii (Vladivostok: Iosif Korot).

—. 1922c. Sdelali li my oshibki na pervom nesotsialisticheskom s"ezde? (Vladivostok: Iosif Korot).

-. 1922d. Zadachi Nesotsialisticheskogo dvizhenizâ: doklad prochitannyi na otkrytom zasedanii Soveta S"ezda Predstavitelei nesotsialisticheskogo naseleniia Dal'nego Vostoka 26 marta 1922 goda (Vladivostok: Tip. Voennoŭ akademii).

—. 1923. Ėtnos - issledovanie osnovnykh printsipov izmeneniza ètnicheskikh $i$ ètnograficheskikh îvleniǔ (Shanghai: Sibpress).

—. 1938a. 'Znachenie dinastii Romanovykh dlîa Rossii (nachalo)', Kitaŭskiŭ blagovestnik 36 (9): 17-19.

—. 1938b. 'Znachenie dinastii Romanovykh dlía Rossii (okonchanie)', Kitaŭskiŭ blagovestnik 36 (10-11): 15-23.

Shirokogorova, E. N. 1919. 'Severo-Zapadnaîa Man'chzhuriîâ (geograficheskiı̌ ocherk po dannym marshrutnykh nabliûdeniǔ)', Uchenye zapiski istorikofilologicheskogo fakul'teta v Vladivostoke 1: 109-46.

Shternberg, L. I. A. 2009. 'Anthropological Suggestions and Perspectives During the Revolutionary Years In Russia', Ab Imperio 1: 271-77.

Smele, J. D. 2015a. 'Khoravat, Dmitrii Leondinovich', in Historical Dictionary of the Russian Civil Wars, 1916-1926, ed. by J. D. Smele (London: Rowman \& Littlefield), 571-72.

—. 2015b. The "Russian" Civil Wars, 1916-1926: Ten Years that Shook the World (Oxford: Oxford University Press).

Smith, C. F. 1975. Vladivostok under Red and White Rule: Revolution and Counterrevolution in the Russian Far East, 1920-1922 (Seattle, WA: University of Washington Press).

Speshnev, N. A. 2004. Pekin-strana moego detstva. Kită̌skaîa rapsodiua. Zapiski sinkhronnogo perevodchika (St Peterburg: Bel'veder). 
Stephan, J. J. 1978. The Russian Fascists: Tragedy and Farce in Exile, 1925-1945 (New York: Harper \& Row).

Vernadskiǔ, V. I. 1994. Dnevniki 1917-1921 (oktîabr' 1917-iânvar' 1920) (Kiev: Naukova dumka).

Wang Mingming. 2010. 'The Intermediate Circle', Chinese Sociology $\mathcal{E}$ Anthropology 42 (4): 62-77, https://doi.org/10.2753/CSA0009-4625420404.

Zhuravlev, V. V., ed. 2012. Privetstvennye poslanīa Verkhovnomu Praviteliu $i$ Verkhovnomu glavnokomanduîushchemu admiralu A. V. Kolchaku. Noîabr' 1918noîabr' 1919 g. (St Peterburg: European University in St Petersburg Press).

\section{Archival References}

APS: American Philosophical Society, Philadelphia, Pennsylvania

APS Boas Collection, Box 82. A letter from F. Boas to S. M. Shirokogoroff, 13 Jul. 1920. Manuscript. 1 folio.

\section{AS: Academia Sinica, Taipei}

AS Yuan 46-26. A letter from S. M. Shirokogoroff to Y. P. Tsai, 15 Jul. 1930.

BN PAU i PAN: Scientific Library of the Polish Academy of Skills and the Polish Academy of Sciences, Kraków

BN PAU i PAN 4600-6: 4-8. Pis'mo S. M. Shirokogorova V. L. Kotvichu, 28 Apr. 1924. Manuscript. 4 folios.

BN PAU i PAN 4600-6: 9-13. Pis'mo S. M. Shirokogorova V. L. Kotvichu, 24 Aug. 1924. Manuscript. 5 folios.

BN PAU i PAN 4600-6: 65-66. Pis'mo S. M. Shirokogorova V. L. Kotvichu, 2 Oct. 1927. Manuscript. 2 folios.

BN PAU i PAN 4600-7: 32-32v. Pis'mo S. M. Shirokogorova V. L. Kotvichu, 24 Apr. 1931. Manuscript. 1 folio.

BN PAU i PAN 4600-7: 54-57. Pis'mo S. M. Shirokogorova V. L. Kotvichu, 6 Feb 1933. Manuscript. 4 folios.

BN PAU i PAN 4600-7: 67-69v. Pis'mo S. M. Shirokogorova V. L. Kotvichu, 5 Aug. 1935. Manuscript. 3 folios.

BN PAU i PAN 4600-7: 70-70v. Pis'mo S. M. Shirokogorova V. L. Kotvichu, 28 Nov. 1935. Manuscript. 1 folios. 


\section{Chu.Cam: Archive of Churchill College, Cambridge}

Chu.Cam PIRI 22/3. A letter from S. M. Shirokogoroff to G. Pitt Rivers, 14 Nov. 1935. Typeset. 2 folios.

Chu.Cam PIRI 11/2. Pitt Rivers, G. Science of Population. Interim Report on Scientific Organization and Classification. [Undated]. 6 folios.

\section{EAA: Estonian Historical Archive, Tartu}

EAA 384.1.3443. Lichnoe delo I. I. Shirokogorova, 2 Jun. 1915-11 Jun. 1916. 46 folios.

EAA 402.1.29599. Lichnoe delo V. M. Shirokogorova. 1906. 57 folios.

EAA 402.1.29600. Lichnoe delo I. I. Shirokogorova, 1 June 1907-28 May 1917. 105 folios.

EAA 402.1.29601. Lichnoe delo M. M. Shirokogorova, 1912. 47 folios.

EAA 402.1.29602. Lichnoe delo M. M. Shirokogorova, 1913. 6 folios.

EAA 402.3.1864. Lichnoe delo I. I. Shirokogorova, 1 Jun. 1907-20 Mar. 1917. 7 folios.

EVR: Elena V. Robinson's Personal Archive, St Petersburg Photographic collection

GARF: State Archive of the Russian Federation, Moscow

GARF 102 D-7-207(1910)-2877: 12-13. Kopiîa pis'ma I. I. Shirokogorova V. M. Shirokogorovu, 30 Aug. 1910. Typescript. 2 folios

GARF 124-55-338: 2. Pis'mo A. F. Kerenskogo Komitetu obshchestvennol̆ bezopasnosti, 30 Mar. 1917. Typescript. 1 folio.

GARF 393-86-639. Lichnoe delo V. M. Shirokogorova, 26 Aug. 1923-20 May 1924. 33 folios.

HILA: Hoover Institution Library and Archives, Stanford University, California

HILA 26001-141. Pis'mo S. M. Shirokogorova L. E. Berkovichu, 21 Jan. 1910. 1 folio.

HILA 1A-5 [1938-1939]. Serebrennikov Collection. Dnevnik I. I. Serebrennikova. HILA 1A-5 [1938-1939]. Serebrennikov Collection. Photographs. 
MAE: [Numbered Collections of] Peter the Great Museum of Anthropology and Ethnography (Kunstkamera), Russian Academy of Sciences, St Petersburg

MAĖ 2639-465-470. Fotografii kitaĭskikh piketov, 1915-1916. Photo prints. $102 \times 40 \mathrm{~mm}$.

MRC: Museum of Russian Culture, San Francisco, California

MRC 3-2-31-6. Lifanovskiı̆, A. A. Opisanie plavanira po r. Arguni v 1915 g. Typescript. 43 folios.

MRC 45-3-9. Ofitsial'nye dokumenty generala Khorvata. Prikaz Vremennogo pravitelia No 43 (Vladivostok, 18 Oct. 1918)... po Diplomaticheskoŭ kantseliarii o naznachenii S. M. Shirokogorova chinovnikom osobykh porucheniǔ V klassa s 9 iîulîa 1918 g. 1 folio.

MRC 45-4-1. Kantseliaririâ generala Khorvata. Otchëty i finansovye dokumenty. MRC Photographic and leaflet collection.

NA RGO: Scientific Archive of the Russian Geographical Society, St Petersburg

NA RGO 24-1-78. Protokoly № 1-4 II Otdela [Komissii] sostavlenira ètnograficheskikh kart Sibiri i Sredneı̌ Azii i dr[ugie] materialy [dated 19101924]. 124 folios.

NA RGO 109-1-15. L. IA. Shternberg, F. K. Volkov, N. M. Mogilianskiǐ. Zapiska ob ètnografii i antropologii [undated]. 13 folios.

RGIA DV: Russian State Historical Archive of the Far East, Vladivostok

RGIA DV P-289-2-1573: 11-11v. Pis'mo dotsenta Dal'nevostochnogo gosudarstvennogo universiteta A. M. Mervarta dekanu Vostochnogo fakul'teta s otzyvom o S. M. Shirokogorove. 19 Jan. 1922. 1 folio.

RGIA DV P-289-2-1573: 16-16v. Pis'mo S. M. Shirokogorova rektoru Dal'nevostochnogo universiteta. 15 Dec. 1922. 1 folio.

RGIA DV P-289-2-1573: 17-18v. Pis'mo S. M. Shirokogorova dekanu Vostochnogo fakul'teta. 14 Nov. 1922. 2 Folios.

RGIA DV P-289-2-1573: 26-26v. Postanovlenie sobraniâa Vostochnogo fakul'teta o priznanii S. M. Shirokogorova privat-dotsentom s porucheniem chteniia lekÆsiir. 25 Jan. 1922. 1 folio. 
RGIA DV P-289-2-1573: 27-28. Biograficheskaîa spravka, spisok èkspeditsiǐ, komandirovok i trudov S. M. Shirokogorova. 1922. 2 folios.

SPF ARAN: St Petersburg Filial of the Archive of the Russian Academy of Sciences

SPF ARAN 142-1(1918)-68: 140-144v. Pis'mo S. M. Shirokogorova L. IA. Shternbergu, 4 Aug. 1916. Manuscript. 5 folios.

SPF ARAN 142-1(1918)-71: 44. Pis'mo S. M. Shirokogorova L. TA. Shternbergu, 13 Sep. 1917. Typeset. 1 folio.

SPF ARAN 142-1(1918)-72: 17-17v. Pis'mo S. M. Shirokogorova V. V. Radlovu, 1 Aug. 1917. Manuscript. 1 folio.

SPF ARAN 142-1(1918)-72: 22-23. Pis'moS. M. Shirokogorova L. TA. Shternbergu, 17 May 1918. Manuscript. 2 folios.

SPF ARAN 142-1(1922)-4: 195-96. Otchët S. M. Shirokogorova v Rossiǔskuîu Akademiîu Nauk, 26 Oct. 1922. Typeset. 2 folios.

SPF ARAN 142-1(1923)-3: 13. Pis'mo L. IA. Shternberga S. M. Shirokogorovu, 28 Feb. 1923. Manuscript. 1 folio.

SPF ARAN 142-1(1924)-4: 11-12v. Otchët S. M. Shirokogorova v Rossiǔskuîu Akademiîu Nauk, 26 Jan. 1923. Typeset. 2 folios.

SPF ARAN 282-2-319: 21-22v. Pis'mo S. M. Shirokogorova L. IA. Shternbergu, 11 May 1917. Manuscript. 2 folios.

SPF ARAN 282-2-319: 23-24v. Pis'mo S. M. Shirokogorova L. IA. Shternbergu, 28 Aug. 1917. Manuscript. 2 folios.

SPF ARAN 282-2-319: 25-27v. Pis'mo S. M. Shirokogorova L. IA. Shternbergu, 04 Dec. 1922. Manuscript. 3 folios.

SPF ARAN 820-3-879: 1-1v. Pis'mo I. I. Shirokogorova V. M. Alekseevu, 03 Mar. 1941. Manuscript. 1 folio.

SPF ARAN 820-3-880: 40-43. Pis'mo S. M. Shirokogorova V. M. Alekseevu, 9 Apr. 1931. Manuscript. 7 folios.

SPF ARAN 849-5-805: 1-269v. S. M. and E. N. Shirokogorovy. Konspekty lektsiǔ. Vypiski iz literatury. In Russian and French. 1906-1911.

\section{TsGIA SPb: Central State Historical Archive of St Petersburg}

TsGIA SPb 14-3-59098. Lichnoe delo S. M. Shirokogorova. 1911. 41 folios 
TumA: Donald Tumanisonis's Personal Archive, Horten, Norway

TumA 109. Incoming Correspondence Letter 109. Letter from Ivan I. Gapanovich to Donald Tumanisonis, 1 May 1979.

TumA 183. Incoming Correspondence Letter 183. Letter from Ivan I. Gapanovich to Donald Tumanisonis, 8 Jun. 1980.

TumA 243. Incoming Correspondence Letter 243. Letter from the Archpriest of the St. Aleksandr Nevsky Cathedral in Paris to Donald Tumanisonis, 8 Jan 1981.

TumA 1915/16. Photocopied Field Diary of Sergei Shirokogoroff, 1915-1916. 